\title{
Motivational Factors Affecting Construction Labor Productivity: A Review
}

\author{
Nguyen Van $\operatorname{Tam}^{1, *}$ \\ ${ }^{1}$ Faculty of Construction Economics and Management, National University of Civil Engineering, Hanoi, Vietnam \\ *Corresponding author: tamnv2@nuce.edu.vn
}

Received 5 September 2021; Revised 24 September 2021; Accepted 5 October 2021

\begin{abstract}
Research on motivational factors affecting construction labor productivity (CLP) has attracted numerous researchers worldwide many years so far. This study aims to review studies on motivational factors affecting CLP from the outcomes of previous studies. Based on a comprehensive review, publications on this domain were analyzed in terms of geographical distribution, adopted research methods, common motivational factors, and knowledge gaps. The findings indicated that the majority of studies were carried out in the Asia continent, followed by Europe, Africa, and America. Also, almost studies adopted methods of empirical research for identifying and evaluating of motivational factors with a prevalent procedure that includes five stages, namely, identifying motivational factors based on a review of existing literature; pilot study; data collection; data analysis; and concluding critical motivational factors. Additionally, the results also revealed that the mostly identified motivational factors contain rewards; good relationship; promotion opportunities; job security; good supervision; the amount of salary; and a good work environment. It is recommended that engineering managers, project managers, employers should use the findings of this study to make policies or decisions to ensure effective management and improve construction workforce productivity.
\end{abstract}

Keywords: Motivational Factor; Labor Productivity; Construction Industry; Literature Review

\section{Introduction}

The construction industry is one of the largest and most resource-consuming industries in the world, accounting for $50 \%$ of raw materials and $40 \%$ of global energy consumption (Corporation, 2018; Hazeltine, 1976). Besides, the construction sector value contributes from $6 \%$ to $9 \%$ of an economy's gross domestic product (GDP) (Arditi \& Mochtar, 2000; Chitkara, 1998). However, in comparison with other industries, the construction industry seems to lag in the using and adoption the technology advances and employs numerous unskilled construction workers, hence, productivity in the construction primarily depends on the workforce's effort and performance (Haas et al., 2008; Jarkas, 2010; Ng et al., 2004). Consequently, in many countries, however, the construction sector is facing one of the most problems that low-level labor productivity (Ayele \& Fayek, 2019; Egan, 1998; Jarkas \& Bitar, 2012; Lim \& Alum, 1995; Segerstedt et al., 2010; Timmer et al., 2010; Tookey, 2011). This is a primary cause sequence that decreases GDP, increases inflationary pressure, social conflicts, and mutual suspicion to the countries' economy (Dixit et al., 2017; Drucker, 1993; Hamza et al., 2019; Shoar \& Banaitis, 2019). Laborers' motivation as a 
determinant may lead to stimulating construction productivity enhancement (Barg et al., 2014; Borcherding, 1976; Hewage \& Ruwanpura, 2006; Laufer \& Borcherding, 1981; Maloney \& McFillen, 1987; Schrader, 1972). The workforce in construction projects is one of the difficult factors to supervise, manage, and control. Therefore, it is critically important to determine the motivational factors influencing CLP (Hamza et al., 2019; Kazaz \& Ac1kara, 2015). Understanding the motivational factors influencing CLP may lead to the development of strategies to reduce inefficiencies and improve construction project performance through more effective construction workforce management (Ailabouni et al., 2009; Hamza et al., 2019; Robles et al., 2014). Therefore, a comprehensive and in-depth review of motivational factors impacting CLP should be conducted in order to provide an extensive picture to help researchers can focus further studies, thereby maximizing the chance for enhancement CLP.

The goal of the present study is to comprehensively review of previous studies have been conducted to identify and address motivational factors affecting labor productivity in the construction industry. To achieve this, specific objectives are as follows:

(1) To identify a list of motivational factors influencing CLP through a review of different studies were carried out so far by using available scientific databases.

(2) To ascertain the geographical distribution of motivational factors affecting CLP.

(3) To determine research methodology to be adopted in studies on motivational factors affecting CLP.

(4) To identify the most common motivational factors affecting CLP from previous studies.

(5) To determine knowledge gaps related to studies on motivational factors affecting CLP in order to recommend suggestions or directions for further researches.

The results of this study could be referred by not only scientific researchers, who are interested in motivational factors affecting CLP but also key stakeholders of the construction projects (i.e., project managers, contractors, owners) to help them develop a deeper and wider understanding of the motivational factors influencing the productivity of the construction workforce. As a result, they can focus, acting upon, and controlling the primary motivational factors affecting CLP towards improving construction project performance and maximizing project profit.

\section{Past studies}

Motivation has been defined as "providing a drive to act to satisfy needs or desires" (Cox et al., 2005). According to (Funso, 2016), it is a positive charge that produces motivation current that moves an individual to expend the effort that will lead to the attainment of organizational goals and meet personal needs; whereas, (Jenkins et al., 1982) stated that motivation is intangible, a hypothetical construct that is used to explain human behavior. Another perspective, (Schmid \& Adams, 2008) explained that motivation is commonly sourced from intrinsic or extrinsic motives. Extrinsic motivation reflects an instrumentality between the activity and some separable consequences such as tangible or verbal rewards; hence, satisfaction comes not from the activity itself but rather from the extrinsic consequences to which the activity leads. In contrast, intrinsic motivation reflects individuals doing an activity because they find it interesting and derive spontaneous satisfaction from the activity itself (Gagné \& Deci, 2005).

In many years so far, research on motivation has been concerned by numerous researchers around the world. For the construction industry, various studies have been researched on motivational factors affecting CLP in order to identify, evaluate these factors, and recommend the measurements to improve labor productivity in the construction sector. To improve construction project performance, motivational factors influencing CLP should be identified and addressed appropriately (Hasan et al., 2018). That is why various motivational factors were identified and assessed by many previous studies. For example, (Aghayeva \& Ślusarczyk, 2019) identified 25 motivational factors affecting CLP in Azerbaijan. Accordingly, top factors were assessed impacting CLP such as amount of remuneration; high responsibility job; job security; bonuses and fringe benefits; and challenging task. In Australia, 25 motivational factors influencing CLP were determined by (Doloi, 2007); factors of job security; work appreciation and reward; work 
environment; prospect of promotion; and geographical position were found as determinant factors to impact on CLP. In Malaysia, (Ohueri et al., 2018) stated that effective management and supervision; financial incentives; effective management; viable construction practices; and sufficient reward system were the most motivational factors affecting CLP; whereas, factors of bonus or rewards; amount of salary; friendliness and helpfulness of the coworkers; amount of freedom in your work; and chance for getting a promotion were important factors affecting CLP in Canada. Table 1 indicates the top motivational factors affecting CLP which were ranked by different researchers.

\section{Method}

To comprehensively review and analyze and the findings of previous studies in a research area or a particular topic, the methodological analysis of publications in scientific journals is very important (Tsai \& Lydia Wen, 2005). The present study carries out a review related papers based on an examination literature on the identification of motivational factors influencing CLP. It synthesizes and assesses the current state of existing papers to identify patterns and trends in the existing research body and recommends new future studies (Hasan et al., 2018).

To begin with, academic journals are sought with publications on motivational factors impacting CLP. The list of previous studies was identified by the use of a powerful "Scopus" search engine for a comprehensive on the specific area (Osei-Kyei \& Chan, 2015; Van \& Quoc, 2021). This is because "Scopus" covers most article databases in numerous different scientific areas such as management, engineering, accounting, and business (Hong \& Chan, 2014). Besides, "Scopus" was considered in terms of its accuracy and coverage better than other search engines such as Google Scholar, PubMed, or Web of Science (Falagas et al., 2008). In addition, the Scopus search engine has been employed in similar research of literature review in the field of construction management (Hong \& Chan, 2014; Van Tam, 2021; Yuan \& Shen, 2011).

In order to critically analyze and facilitate a clear representation of the trend of motivational factors affecting CLP research, a comprehensive search was conducted under the "title/abstract/keyword" fields of the search engine "Scopus". The search keywords involved "motivational factors", and "motivational factors affecting", which were limited to the area of the CLP by the use of keyword "labor productivity", "construction labor productivity", and "construction productivity". Studies include these specific terms in the title, abstract, or keywords that were considered to meet the requirements of this study. The full search code is as follows:

TITLE-ABS-KEY ("motivational factors" OR "motivational factors affecting” AND TITLE-ABS-KEY ("labor productivity” OR “construction labor productivity” OR “construction productivity”) AND DOCTYPE (ar OR re) AND (LIMIT-TO (LANGUAGE, “English”)) AND (LIMIT-TO (SRCTYPE, “j”)).

In this regard, all journals adopted are prominent "construction research" journals. In these scientific journals, this study carefully researched through the titles of all the articles appearing in each issue of all the volumes looking for any papers which were to be concerned with "motivational factors" and "construction labor productivity". Next, all publications in journals, which were published under the broad groups of "editorial", "book review", "articles in press", "letter to the editor", "closures and discussion", "introduction", and "briefing sheet", were removed from the analysis (Ke et al., 2009; Osei-Kyei \& Chan, 2015). In addition, the abstracts of publications that had some relevance to "motivational factors" were examined closely and the ones which had the keyword "construction labor productivity" in the abstract were considered for this study (Hamza et al., 2019). Consequently, a total of 27 publications on this domain were considered for further analysis. Figure 1 illustrates the research framework for this study.

Following the compilation of selected papers, this study analyzed the data in order to identify: Geographical distribution of motivational factors affecting CLP; research methodologies to be adopted in studies on motivational factors affecting CLP; the most common motivational factors affecting CLP and recommendations for further studies. 
Table 1. Summary of previous studies on motivational factors affecting construction labor productivity

\begin{tabular}{|c|c|c|c|}
\hline Study & Region & $\begin{array}{c}\text { Total } \\
\text { factors } \\
\text { identified } \\
\end{array}$ & Top motivational factors affecting construction labor productivity \\
\hline Hewage (2007) & Canada & 23 & $\begin{array}{l}\text { (1) Bonus or rewards; (2) Amount of salary; (3) Friendliness and helpfulness of the coworkers; (4) Amount of freedom in } \\
\text { your work; (5) Chance for getting a promotion }\end{array}$ \\
\hline Doloi (2007) & Australia & 25 & $\begin{array}{l}\text { (1) Job security; (2) Work appreciation and reward; (3) Work environment; (4) Prospect of promotion; (5) Geographical } \\
\text { position }\end{array}$ \\
\hline $\begin{array}{l}\text { Dwivedula and } \\
\text { Bredillet (2010) }\end{array}$ & $\begin{array}{l}\text { Multi- } \\
\text { nation }\end{array}$ & 18 & (1) Employee development; (2) Work climate; (3) Perceived equity; (4) Work objectivity; (5) job security \\
\hline $\begin{array}{l}\text { Funso et al. (2016b; } \\
\text { 2016a) }\end{array}$ & Nigeria & 16 & (1) Job security; (2) Good salary; (3) Compliance with safety; (4) Appreciation of effort; (5) Bonus \\
\hline Jarkas et al. (2014) & Qatar & 38 & $\begin{array}{l}\text { (1) Lack of financial incentive schemes; (3) Slow decision-making process by owners; (3) Remuneration scale; (4) Delay in } \\
\text { responding to requests for information; (5) Shortage of skilled labor force }\end{array}$ \\
\hline $\begin{array}{l}\text { Al-Abbadi and } \\
\text { Agyekum-Mensah } \\
(2019)\end{array}$ & Jordan & 16 & $\begin{array}{l}\text { (1) Personal growth/career improvement; (2) Pay on time; (3) Decision-making ability; (4) Decent and respectful job; (5) } \\
\text { Rewards }\end{array}$ \\
\hline Olomolaiye (1990) & UK & 28 & (1) Good relations with mates; (2) Good safety program; (3) The work itself; (4) Overtime; (5) Level of pay \\
\hline Shin et al. (2013) & Korea & 25 & (1) Economical factors; (2) Social factors; (3) Psychological factors \\
\hline $\mathrm{Ng}$ et al. (2004) & $\begin{array}{l}\text { Hong } \\
\text { Kong }\end{array}$ & 7 & (1) Rework; (2) Overcrowded work areas; (3) Crew interfacing; (4) Tool availability; (5) Inspection delays \\
\hline Khan et al. (2011) & Pakistan & 20 & $\begin{array}{l}\text { (1) Free lunch; (2) Amount of pay/wages (3) Bonus on Eid; (4) On-time payment; (5) Incentive payments and financial } \\
\text { rewards }\end{array}$ \\
\hline Kazaz et al. (2008) & Turkey & 37 & (1) Quality of site management; (2) Material management; (3) On-time payment; (4) Systematic flow of work; (5) Supervision \\
\hline Parkin et al. (2009) & Turkey & 18 & (1) Money; (2) Relationships; (3) Enjoyment; (4) Home life; (5) Getting a poor quality meal \\
\hline Zakeri et al. (1997) & Iran & 20 & $\begin{array}{l}\text { (1) Weather temperature; (2) Lack of working area; (3) Skillfulness; (4) Average workweek (hour); (5) Project management } \\
\text { efficiency }\end{array}$ \\
\hline $\begin{array}{l}\text { Ghoddousi et al. } \\
\text { (2015) }\end{array}$ & Iran & 12 & $\begin{array}{l}\text { (1) Fairness of pay; (2) Incentives and financial rewards; (3) On-time payment; (4) Good working facilities; (5) Safety and } \\
\text { health at work }\end{array}$ \\
\hline $\begin{array}{l}\text { Nasirzadeh and } \\
\text { Nojedehi (2013) }\end{array}$ & Iran & 6 & $\begin{array}{l}\text { (1) Empowerment; (2) Delay in salary payment; (3) Job security; (4) The proportion of labor's salary and responsibility; (5) } \\
\text { interpersonal interaction }\end{array}$ \\
\hline $\begin{array}{l}\text { Momade and Hainin } \\
\text { (2019) }\end{array}$ & Qatar & 10 & $\begin{array}{l}\text { (1) Achievement; (2) Proper recognition and rewards, (3) Poor work conditions; (4) Poor administration policy; (5) Poor } \\
\text { work relationship }\end{array}$ \\
\hline
\end{tabular}


Table 1. Summary of previous studies on motivational factors affecting construction labor productivity (continued)

\begin{tabular}{|c|c|c|c|}
\hline Study & Region & $\begin{array}{c}\text { Total } \\
\text { factors } \\
\text { identified }\end{array}$ & Top motivational factors affecting construction labor productivity \\
\hline $\begin{array}{l}\text { Gunduz and Abdi } \\
(2020)\end{array}$ & Qatar & 19 & $\begin{array}{l}\text { (1) Sharing specific design solutions with partners when needed; (2) Sharing technical solutions in work implementation; (3) } \\
\text { Share experience in defining the scope of works and specifications to subcontractors; (4) Having better utilization of } \\
\text { construction equipment and machinery; (5) Enhance health, security, safety and environmental control }\end{array}$ \\
\hline Ohueri et al. (2018) & Malaysia & 23 & $\begin{array}{l}\text { (1) Effective management and supervision; (2) Financial incentives; (3) Effective management; (4) Viable construction } \\
\text { practices; (5) Sufficient reward system }\end{array}$ \\
\hline $\begin{array}{l}\text { Jarkas and } \\
\text { Radosavljevic (2013) }\end{array}$ & Kuwait & 23 & $\begin{array}{l}\text { (1) Payment delay; (2) Rework; (3) Lack of financial incentive scheme; (4) The extent of change orders during execution; (5) } \\
\text { Incompetent Supervisors }\end{array}$ \\
\hline $\begin{array}{l}\text { Shroff and Sridhar } \\
\text { (2011) }\end{array}$ & India & 19 & (1) Job training; (2) Good salary; (3) Recognition from peers, (3) Growth; (4) Challenging task; (5) Monetary benefits \\
\hline Ugulu et al. (2016) & $\begin{array}{l}\text { South } \\
\text { Africa }\end{array}$ & 25 & (1) Days off; (2) Financial Incentives; (3) Skills enhancement; (4) Salaries paid on time; (5) Job enlargement \\
\hline Enshassi et al. (2007) & Palestine & 6 & $\begin{array}{l}\text { (1) Payment delay; (2) Lack of financial motivation system; (3) Lack of labor recognition programs, (4) Non-provision of } \\
\text { transport means; (5) Lack of places for eating and relaxation }\end{array}$ \\
\hline Rivas et al. (2011) & Chile & 41 & (1) Materials; (2) Rework; (3) Equipment and trucks; (4) Tools; (5) Interference \\
\hline $\begin{array}{l}\text { McFillen and } \\
\text { Maloney (1988) }\end{array}$ & USA & 5 & (1) Feeling of accomplishment; (2) Opportunities; (3) Peer rewards; (5) Feedback; (5) Supervisor rewards \\
\hline $\begin{array}{l}\text { Ruthankoon and } \\
\text { Ogunlana (2003) }\end{array}$ & Thailand & 18 & (1) Achievement; (2) Recognition; (3) Work if self; (4) Responsibility; (5) Advancement \\
\hline $\begin{array}{l}\text { Aghayeva and } \\
\text { Ślusarczyk (2019) }\end{array}$ & Azerbaijan & 25 & $\begin{array}{l}\text { (1) Amount of remuneration; (2) High responsibility job; (3) Job security; (4) Bonuses and fringe benefits; (5) Challenging } \\
\text { task }\end{array}$ \\
\hline
\end{tabular}




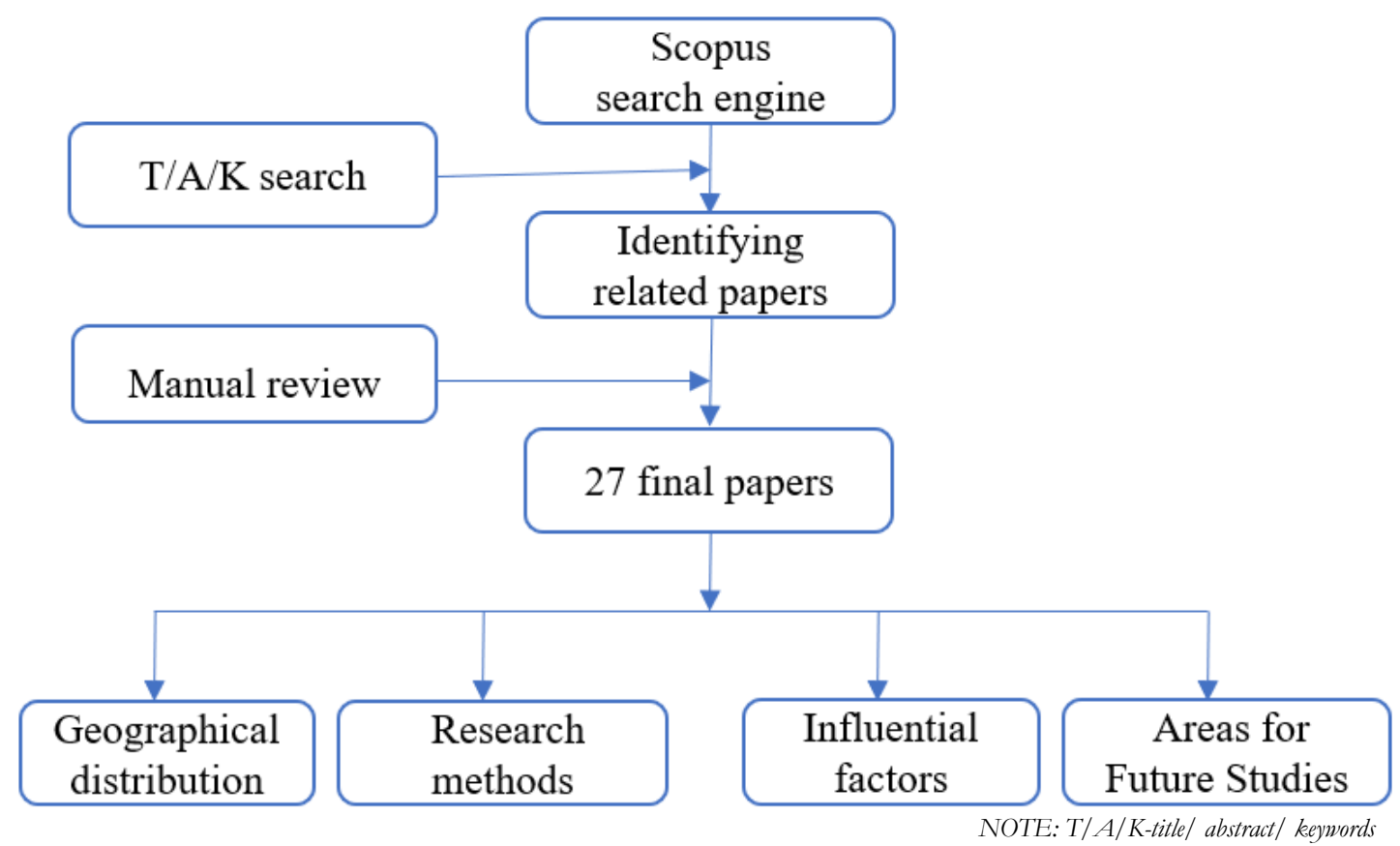

Figure 1. Research framework for the study

\section{Findings}

\subsection{Regional distribution of motivational factors affecting construction labor productivity studies}

Table 2 provides the geographical spread of the previous studies over different continents. It can be noted that the majority of studies were carried out in the Asian nations (59\%) followed by European nations (19\%), Africa (11\%), America (7\%), and Australia Pacific (4\%). Besides, the analysis results indicated that Qatar (3), Iran (3), Turkey (2), and Nigeria (2) have a higher number of publications to contribute to studying motivational factors influencing CLP.

Concerning the geographical areas, the majority of the researchers in Africa have revealed that: Job security (Funso, 2016; Funso et al., 2016a, 2016b); Days off (Ugulu et al., 2016); Good salary (Funso et al., 2016b); Financial Incentives (Funso, 2016; Ugulu et al., 2016); Compliance with safety (Funso et al., 2016a) and Skills enhancement (Ugulu et al., 2016) are the critical motivational factors impacting labor productivity in the construction sector, whereas, (Doloi, 2007) stated that top five motivational factors influencing CLP in Australia Pacific that are: Job security; Work appreciation and reward; Work environment, employer's recognition; Prospect of promotion; Geographical position.

In North America countries, the findings from studies indicated that top motivational factors influencing CLP as follows: Bonus or rewards (Kasun Neranja Hewage, 2007; Hewage \& Ruwanpura, 2006; McFillen \& Maloney, 1988); Working conditions (Hewage, 2007; Hewage \& Ruwanpura, 2006); Amount of salary (Hewage, 2007); Feeling of accomplishment (McFillen \& Maloney, 1988); Management and supervision (Hewage, 2007; McFillen \& Maloney, 1988). However, in Europe, the numerous researchers explained that Good relations (Aghayeva \& Ślusarczyk, 2019; Olomolaiye, 1990; Parkin et al., 2009); Material management (Kazaz et al., 2008; Rivas et al., 2011); Quality of site management (Kazaz et al., 2008; Rivas et al., 2011); Level of payment (Aghayeva \& Ślusarczyk, 2019; Kazaz et al., 2008; Olomolaiye, 1990; Parkin et al., 2009) are the main motivational factors impacting CLP.

In the Asia continent, numerous researchers stated that the primary motivational factors affecting CLP include: Good salary (Al-Abbadi \& Agyekum-Mensah, 2019; Ghoddousi et al., 2015; Jarkas \& Radosavljevic, 2013; Jarkas et al., 2014; Khan et al., 2011; Nasirzadeh \& Nojedehi, 2013; Ohueri et al., 2018; Shroff \& Sridhar, 2011); Achievement (Al-Abbadi \& Agyekum-Mensah, 2019; Hai \& Van Tam, 2019; Momade \& Hainin, 2019; Nasirzadeh \& Nojedehi, 2013; Ruthankoon \& Ogunlana, 2003; Shroff \& Sridhar, 2011); Rewards (Al-Abbadi \& Agyekum-Mensah, 2019; 
Table 2. Identification of the motivational factors related to CLP in different regions

\begin{tabular}{|c|c|c|c|}
\hline Number of studies & Regions & Continent & Percentage \\
\hline $3 / 27$ & Qatar & \multirow{12}{*}{ Asia } & \multirow{12}{*}{$59 \%$} \\
\hline $1 / 27$ & Jordan & & \\
\hline $1 / 27$ & Korea & & \\
\hline $1 / 27$ & Hong Kong & & \\
\hline $1 / 27$ & Pakistan & & \\
\hline $3 / 27$ & Iran & & \\
\hline $1 / 27$ & Malaysia & & \\
\hline $1 / 27$ & Kuwait & & \\
\hline $1 / 27$ & India & & \\
\hline $1 / 27$ & Vietnam & & \\
\hline $1 / 27$ & Palestine & & \\
\hline $1 / 27$ & Thailand & & \\
\hline $1 / 27$ & Canada & \multirow{2}{*}{ America } & \multirow{2}{*}{$7 \%$} \\
\hline $1 / 27$ & USA & & \\
\hline $1 / 27$ & Australia & Australia Pacific & $4 \%$ \\
\hline $1 / 27$ & Chile & \multirow{4}{*}{ Europe } & \multirow{4}{*}{$19 \%$} \\
\hline $2 / 27$ & Turkey & & \\
\hline $1 / 27$ & UK & & \\
\hline $1 / 27$ & Azerbaijan & & \\
\hline $1 / 27$ & South Africa & Africa & $11 \%$ \\
\hline
\end{tabular}

Ghoddousi et al., 2015; Jarkas \& Radosavljevic, 2013; Khan et al., 2011; Momade \& Hainin, 2019; Ohueri et al., 2018; Shin, Kim et al., 2013; Van Tam, et al., 2018); Recognition (Al-Abbadi \& Agyekum-Mensah, 2019; Enshassi et al., 2007; Momade \& Hainin, 2019; Nasirzadeh \& Nojedehi, 2013; Ruthankoon \& Ogunlana, 2003; Shroff \& Sridhar, 2011); Supervision (Jarkas \& Radosavljevic, 2013; Ng et al., 2004; Ohueri et al., 2018).

\subsection{Research methodology adopted in studies on motivational factors affecting construction labor productivity}

The findings of the study was conducted by (Fellows \& Liu, 2015) revealed that there are 5 research approaches including case study, survey, experiment, action research, and ethnographic research. The finding also explained that studies in the construction industry were adopted by case study, survey, and experiment methods. Of which, the experiment method on critical factors influencing CLP would take a long time to give meaningful outcomes and thereby, would be higher costs (Hasan et al., 2018). In addition, the study of (Alinaitwe et al., 2007) indicated that the approach of case study only provides results for a specific project, it would not provide generalizable outcomes as different projects face different issues. Therefore, the survey approach through a structured questionnaire is mainly used in CLP studies as the most preferred data collection tool.

By considering the research approaches of previous studies, the author realized that almost studies adopted the methods of empirical research for identifying and evaluating of motivational factors impacting CLP with a prevalent procedure includes steps as follows (Hamza et al., 2019) identifying motivational factors affecting CLP based on a review of existing literature; pilot study; data collection; data analysis; and concluding critical motivational factors influencing CLP. This process is illustrated in Figure 2, and is explained in the following steps.

Step 1: Identifying motivational factors - The list of motivational factors affecting labor productivity in the construction industry was identified by a comprehensive review previous studies related on the topic area. These factors were categorized into different groups such as motivators or demotivators factors.

Step 2: Pilot study - After motivational factors were listed and grouped by researchers, a questionnaire survey was designed. Before distributing the questionnaire, a pilot study was required to verify the questionnaire and ensure that the information returned by respondents was relevant to the study's objectives (Dwivedula \& Bredillet, 2010; Hewage \& Ruwanpura, 2006; Jarkas et al., 


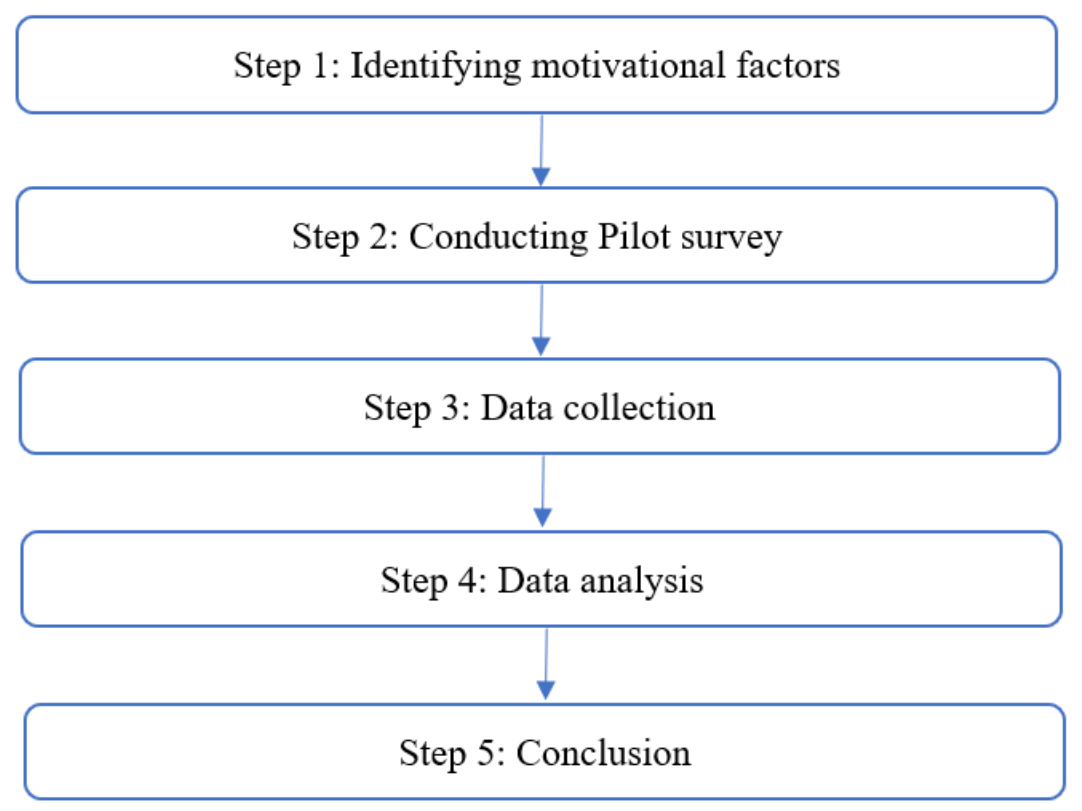

Figure 2. The common process of research method in this domain

2014; Shroff \& Sridhar, 2011; Van Tam et al., 2021). This stage was completed by distributing the questionnaire to experts with many years of experience and in-depth knowledge of the subject. They evaluated the validity of the questionnaire content, commented on the readability of the linguistics, and added additional factors to make the questionnaires more comprehensive (Van Tam et al., 2021).

Step 3: Data collection - in order to collect the needed data, a real questionnaire was conducted by researchers after the pilot test step was completed. In this stage, a structured questionnaire was distributed to construction practitioners (e.g., project managers, contractors, site supervisors, consultants, craftsmen).

Step 4: Data analysis - the collected data were analyzed, evaluated and ranked by several methods such as simple proportion (Doloi, 2007; Hewage \& Ruwanpura, 2006; Kazaz et al., 2008; Ng et al., 2004; Parkin et al., 2009; Rivas et al., 2011; Ugulu et al., 2016), mean score and standard deviation (Al-Abbadi \& Agyekum-Mensah, 2019; Funso et al., 2016a, 2016b; Ghoddousi et al., 2015; Hewage \& Ruwanpura, 2006; Jarkas \& Radosavljevic, 2013; Jarkas et al., 2014; McFillen \& Maloney, 1988; Shin et al., 2013; Shroff \& Sridhar, 2011; Zakeri et al., 1996), reliability (Doloi, 2007; Jarkas et al., 2014; Ohueri et al., 2018), factor analysis (Doloi, 2007; Dwivedula \& Bredillet, 2010; Funso et al., 2016a), relative importance index (Al-Abbadi \& Agyekum-Mensah, 2019; Hemanta Doloi, 2007; Enshassi et al., 2007; Ghoddousi et al., 2015; Gunduz \& Abdi, 2020; Jarkas \& Radosavljevic, 2013; Jarkas et al., 2014; Kazaz et al., 2008; Khan et al., 2011; Momade \& Hainin, 2019; Ohueri et al., 2018; Van Tam et al., 2018), regression analysis (Hemanta Doloi, 2007; Gunduz \& Abdi, 2020; Hai \& Van Tam, 2019; Olomolaiye, 1990), structural equation modeling (Dwivedula \& Bredillet, 2010; $\mathrm{Ng}$ et al., 2004; Olomolaiye, 1990), dynamic modeling (Nasirzadeh \& Nojedehi, 2013), analytic hierarchy process (Aghayeva \& Ślusarczyk, 2019).

Step 5: Concluding critical motivational factors - in the final stage, important motivational factors affecting CLP were discovered on the basis of the data analysis results in the previous stage. Also, discussions were undertaken on the ranked within each group and overall ranking.

\subsection{Most common motivational factors affecting construction labor productivity}

Through a comprehensive review of the 27 publications related to this topic that were analyzed in the present study, the motivational factors influencing CLP for each paper are represented in Table 3. The total number of motivational factors affecting labor productivity in the construction 
industry that were identified from the 27 selected papers is 35 . Nevertheless, the findings provided in Table 3 are factors that were identified in at least two publications.

The number of times a motivational factor was identified by the author is accumulated and presented in Table 3. Numerous studies have been undertaken to identify motivational factors influencing CLP. It is argued that identifying a set of global motivational factors is a critical strategy, this statement usually concludes with the question of labor productivity's reliance on a diverse set of motivational factors (Ghoddousi \& Hosseini, 2012; Jarkas \& Bitar, 2012; Soekiman et al., 2011).

From the results analysis in Table 3, that several common motivational factors impacting CLP, but the top motivational factors that are: Rewards; Good relationship; Promotion opportunities; Job security; Good supervision; Amount of salary; and good work environment. Each of these motivational factors was identified 21;20;20;17;16;15; and 14 times by the 27 publications considered in this study respectively. This evidence indicates how important ten of these motivational factors that have the most effect on CLP.

4.3.1 Rewards. The factor of rewards is one of the motivational factors influencing CLP, so it is not surprising that the factor was identified by 21 different publications as a determinant impacting labor productivity in the construction industry. The finding shows that being rewarded, while not being financially exclusive is key motivational factors that improved the construction workforce's productivity (Al-Abbadi \& Agyekum-Mensah, 2019), which was further supported by the results from previous studies (Aghayeva \& Ślusarczyk, 2019; Al-Abbadi \& Agyekum-Mensah, 2019; Doloi, 2007; Funso et al., 2016b; Ghoddousi et al., 2015; Hai \& Van Tam, 2019; Hewage, 2007; Jarkas \& Radosavljevic, 2013; Jarkas et al., 2014; Khan et al., 2011; McFillen \& Maloney, 1988; Momade \& Hainin, 2019; Shroff \& Sridhar, 2011). In this regard, the study was conducted by (Zakeri et al., 1997) explained that it is improtant to promote and reward employees as a means of increasing their motivation and job satisfaction in order to ehance productivity in the workplace Furthermore, it is recognized the significance of being recognized for their abilities by being rewarded. As a result, managers should provide rewards as a means of demonstrating appreciation for their employees, demonstrating that the managers valued their tasks. Consequently, they tend to devote their entire attention to their organizations, which is the best way to increase their productivity.

4.3.2 Good relationship. A good work environment where have a good relationship between workmates is a key factor for the success of any task (Al-Abbadi \& Agyekum-Mensah, 2019). That is why the factor of the good relationship was identified by 20 publications as a critical motivational factor impacting CLP. Numerous researchers stated that good relationship factor has a significant effect on labor productivity in the construction sector (Aghayeva \& Ślusarczyk, 2019; Doloi, 2008). Possessing good communication is important for work crews and it leads to improved motivation degrees. In contrast, however, a bad relationship will lead to laborers doing tasks alone, which can lead to conflict within the crew that may influence their work motivation and performance levels. Also, the study of (Lingard \& Francis, 2006) revealed that a good relationship between project managers and construction workers is generally believed to effects the performance of construction projects by providing a better working environment for the workforce.

4.3.3 Promotion opportunities. The promotion opportunities factor was identified in 20 different papers on motivating factors affecting CLP. It is obvious that a move up the career ladder impact organizational justice and work satisfaction of any employee (García-Izquierdo et al., 2012). The evidence in the line with the results of previous studies (Doloi, 2007; Dwivedula \& Bredillet, 2010; Hewage, 2007; Ohueri et al., 2018; Olomolaiye, 1990; Parkin et al., 2009; Shin et al., 2013; Shroff \& Sridhar, 2011; Ugulu et al., 2016; Van Tam et al., 2018; Zakeri et al., 1997), which indicated that promotion opportunities have a high effect on labor productivity in the construction industry. Koch (2012) stated that the opportunity of promotion is desirable for any individual, only because employees work harder to compensate for incompetence. Consequently, a promotion at regular intervals of time has an optimistic approach behind and they are generally given to satisfy the psychological needs of laborers in their workplace (Koch \& Nafziger, 2012). Likewise the 
Table 3. Motivational factors affecting construction labor productivity

\begin{tabular}{|c|c|c|c|c|c|c|c|c|c|c|c|c|c|c|c|c|c|c|c|c|c|c|c|c|c|c|c|c|c|}
\hline \multirow{2}{*}{$\begin{array}{c}\text { No } \\
\text { • }\end{array}$} & \multirow{2}{*}{ Motivational factors } & \multicolumn{27}{|c|}{ Publications } & \multirow{2}{*}{ Total } \\
\hline & & 1 & 2 & 3 & 4 & 5 & 6 & 7 & 8 & 9 & 10 & 11 & 12 & 13 & 14 & 15 & 16 & 17 & 18 & 19 & 20 & 21 & 22 & 23 & 24 & 25 & 26 & 27 & \\
\hline 1 & Rewards & $\mathrm{x}$ & $\mathrm{x}$ & & $\mathrm{x}$ & $\mathrm{x}$ & $\mathrm{x}$ & $\mathrm{x}$ & $\mathrm{x}$ & $\mathrm{x}$ & $\mathrm{x}$ & $\mathrm{x}$ & & $\mathrm{x}$ & $\mathrm{x}$ & & $\mathrm{x}$ & & $\mathrm{x}$ & $\mathrm{x}$ & $\mathrm{x}$ & $\mathrm{x}$ & $\mathrm{x}$ & $\mathrm{x}$ & & $\mathrm{x}$ & & $\mathrm{x}$ & 21 \\
\hline 2 & Good relationship & $\mathrm{x}$ & & $\mathrm{x}$ & $\mathrm{x}$ & $\mathrm{x}$ & $\mathrm{x}$ & $\mathrm{x}$ & $\mathrm{x}$ & $\mathrm{x}$ & & & $\mathrm{x}$ & $\mathrm{x}$ & $\mathrm{x}$ & $\mathrm{x}$ & $\mathrm{x}$ & $\mathrm{x}$ & $\mathrm{x}$ & $\mathrm{x}$ & & $\mathrm{x}$ & & & $\mathrm{x}$ & & $\mathrm{x}$ & $\mathrm{x}$ & 20 \\
\hline 3 & Promotion opportunities & $\mathrm{x}$ & $\mathrm{x}$ & $\mathrm{x}$ & $\mathrm{x}$ & $\mathrm{x}$ & $\mathrm{x}$ & $\mathrm{x}$ & $\mathrm{x}$ & $\mathrm{x}$ & & & $\mathrm{x}$ & $\mathrm{x}$ & $\mathrm{x}$ & & $\mathrm{x}$ & & $\mathrm{x}$ & & $\mathrm{x}$ & $\mathrm{x}$ & & & $\mathrm{x}$ & $\mathrm{x}$ & $\mathrm{x}$ & $\mathrm{x}$ & 20 \\
\hline 4 & Job security & $\mathrm{x}$ & $\mathrm{x}$ & $\mathrm{x}$ & $\mathrm{x}$ & $\mathrm{x}$ & $\mathrm{x}$ & $\mathrm{x}$ & $\mathrm{x}$ & $\mathrm{x}$ & & & & $\mathrm{x}$ & $\mathrm{x}$ & $\mathrm{x}$ & & & $\mathrm{x}$ & & $\mathrm{x}$ & $\mathrm{x}$ & & & & & $\mathrm{x}$ & $\mathrm{x}$ & 17 \\
\hline 5 & Good supervision & $\mathrm{x}$ & & & $\mathrm{x}$ & $\mathrm{x}$ & $\mathrm{x}$ & $\mathrm{x}$ & $\mathrm{x}$ & & $\mathrm{x}$ & $\mathrm{x}$ & & $\mathrm{x}$ & & & & & $\mathrm{x}$ & $\mathrm{x}$ & & $\mathrm{x}$ & $\mathrm{x}$ & & $\mathrm{x}$ & & $\mathrm{x}$ & $\mathrm{x}$ & 16 \\
\hline 6 & Amount of salary & $\mathrm{x}$ & & & $\mathrm{x}$ & $\mathrm{x}$ & $\mathrm{x}$ & $\mathrm{x}$ & $\mathrm{x}$ & $\mathrm{x}$ & $\mathrm{x}$ & $\mathrm{x}$ & $\mathrm{x}$ & & $\mathrm{x}$ & $\mathrm{x}$ & & & & & $\mathrm{x}$ & & & & & & $\mathrm{x}$ & $\mathrm{x}$ & 15 \\
\hline 7 & Good work environment & & $\mathrm{x}$ & & & $\mathrm{x}$ & & $\mathrm{x}$ & $\mathrm{x}$ & $\mathrm{x}$ & $\mathrm{x}$ & $\mathrm{x}$ & & $\mathrm{x}$ & $\mathrm{x}$ & & $\mathrm{x}$ & & $\mathrm{x}$ & $\mathrm{x}$ & & & & & $\mathrm{x}$ & & $\mathrm{x}$ & & 14 \\
\hline 8 & Recognition programs & & $\mathrm{x}$ & $\mathrm{x}$ & & $\mathrm{x}$ & $\mathrm{x}$ & & $\mathrm{x}$ & & & & & $\mathrm{x}$ & & & & & $\mathrm{x}$ & $\mathrm{x}$ & $\mathrm{x}$ & $\mathrm{x}$ & & $\mathrm{x}$ & $\mathrm{x}$ & & $\mathrm{x}$ & & 13 \\
\hline 9 & $\begin{array}{l}\text { Participation in decision } \\
\text { making }\end{array}$ & $\mathrm{x}$ & & $\mathrm{x}$ & $\mathrm{x}$ & & $\mathrm{x}$ & $\mathrm{x}$ & $\mathrm{x}$ & $\mathrm{x}$ & & $\mathrm{x}$ & & $\mathrm{x}$ & & & $\mathrm{x}$ & & & & & & & & & & & $\mathrm{x}$ & 11 \\
\hline 10 & On-time payments & & & $\mathrm{x}$ & & & & & & $\mathrm{x}$ & $\mathrm{x}$ & $\mathrm{x}$ & & $\mathrm{x}$ & & $\mathrm{x}$ & & & $\mathrm{x}$ & & & $\mathrm{x}$ & $\mathrm{x}$ & $\mathrm{x}$ & & & & $\mathrm{x}$ & 11 \\
\hline 11 & Work satisfaction & & & & & $\mathrm{x}$ & & $\mathrm{x}$ & & $\mathrm{x}$ & & $\mathrm{x}$ & $\mathrm{x}$ & & $\mathrm{x}$ & & $\mathrm{x}$ & & $\mathrm{x}$ & & & & & & & $\mathrm{x}$ & & $\mathrm{x}$ & 10 \\
\hline 12 & Giving responsibility & & & & & & & $\mathrm{x}$ & $\mathrm{x}$ & $\mathrm{x}$ & & $\mathrm{x}$ & $\mathrm{x}$ & $\mathrm{x}$ & $\mathrm{x}$ & $\mathrm{x}$ & & & & & & & & & & & $\mathrm{x}$ & $\mathrm{x}$ & 10 \\
\hline 13 & $\begin{array}{l}\text { Challenging work } \\
\text { opportunities }\end{array}$ & $\mathrm{x}$ & $\mathrm{x}$ & & $\mathrm{x}$ & $\mathrm{x}$ & & $\mathrm{x}$ & $\mathrm{x}$ & & & & & $\mathrm{x}$ & & & & & & & $\mathrm{x}$ & & & & & & & $\mathrm{x}$ & 9 \\
\hline 14 & $\begin{array}{l}\text { Opportunities to develop } \\
\text { skills and abilities }\end{array}$ & $\mathrm{x}$ & & $\mathrm{x}$ & $\mathrm{x}$ & $\mathrm{x}$ & & $\mathrm{x}$ & & $\mathrm{x}$ & & & & & & & $\mathrm{x}$ & & & & & $\mathrm{x}$ & & & & & & $\mathrm{x}$ & 9 \\
\hline 15 & $\begin{array}{l}\text { Work appreciation and } \\
\text { feedback }\end{array}$ & $\mathrm{x}$ & $\mathrm{x}$ & $\mathrm{x}$ & & $\mathrm{x}$ & $\mathrm{x}$ & $\mathrm{x}$ & & & & & & & & & $\mathrm{x}$ & & & & & & & & & $\mathrm{x}$ & & $\mathrm{x}$ & 9 \\
\hline 16 & Working overtime & & & & & $\mathrm{x}$ & $\mathrm{x}$ & & $\mathrm{x}$ & & & $\mathrm{x}$ & & $\mathrm{x}$ & & & & & & $\mathrm{x}$ & $\mathrm{x}$ & & & & & & & $\mathrm{x}$ & 8 \\
\hline 17 & Freedom in work & $\mathrm{x}$ & & $\mathrm{x}$ & $\mathrm{x}$ & $\mathrm{x}$ & & & & & $\mathrm{x}$ & $\mathrm{x}$ & & & & & & & & & $\mathrm{x}$ & & & & & & & & 7 \\
\hline 18 & Job training & & & & & & & & & & $\mathrm{x}$ & $\mathrm{x}$ & & & & & $\mathrm{x}$ & & $\mathrm{x}$ & & $\mathrm{x}$ & & $\mathrm{x}$ & $\mathrm{x}$ & & & & & 7 \\
\hline 19 & Tools and equipment quality & $\mathrm{x}$ & & & $\mathrm{x}$ & & & $\mathrm{x}$ & & & & & & & & & & & $\mathrm{x}$ & $\mathrm{x}$ & & & & & $\mathrm{x}$ & & & & 6 \\
\hline 20 & Team cooperation & $\mathrm{x}$ & & & $\mathrm{x}$ & & & $\mathrm{x}$ & & & & & & $\mathrm{x}$ & & & & $\mathrm{x}$ & & & & & & & $\mathrm{x}$ & & & & 6 \\
\hline
\end{tabular}


Table 3. Motivational factors affecting construction labor productivity (continued)

\begin{tabular}{|c|c|c|c|c|c|c|c|c|c|c|c|c|c|c|c|c|c|c|c|c|c|c|c|c|c|c|c|c|c|}
\hline \multirow{2}{*}{$\begin{array}{l}\text { No } \\
\text {. }\end{array}$} & \multirow{2}{*}{ Motivational factors } & \multicolumn{27}{|c|}{ Publications } & \multirow{2}{*}{ Total } \\
\hline & & 1 & 2 & 3 & 4 & 5 & 6 & 7 & 8 & 9 & 10 & 11 & 12 & 13 & 14 & 15 & 16 & 17 & 18 & 19 & 20 & 21 & 22 & 23 & 24 & 25 & 26 & 27 & \\
\hline 21 & Organization's reputation & & $\mathrm{x}$ & & & & $\mathrm{x}$ & & & & $\mathrm{x}$ & $\mathrm{x}$ & & $\mathrm{x}$ & & & & & $\mathrm{x}$ & & & & & & & & & & 6 \\
\hline 22 & Relax amenities & $\mathrm{x}$ & & & $\mathrm{x}$ & & & & & & & & & & & & & & & $\mathrm{x}$ & & $\mathrm{x}$ & & $\mathrm{x}$ & & & & $\mathrm{x}$ & 6 \\
\hline 23 & Holidays and free time & $\mathrm{x}$ & & & $\mathrm{x}$ & & & & & & $\mathrm{x}$ & & $\mathrm{x}$ & & & & & & & & & $\mathrm{x}$ & & & & & & & 5 \\
\hline 24 & Good management & & & & & & & & & & $\mathrm{x}$ & $\mathrm{x}$ & & & & & & & & $\mathrm{x}$ & $\mathrm{x}$ & & & & & & & $\mathrm{x}$ & 5 \\
\hline 25 & Status in the organization & & $\mathrm{x}$ & & & & $\mathrm{x}$ & & & $\mathrm{x}$ & & & & & & $\mathrm{x}$ & & & & & & & & & & & & & 4 \\
\hline 26 & Respect receive from others & $\mathrm{x}$ & & & $\mathrm{x}$ & & & $\mathrm{x}$ & & & & & & & & & & & & & & & & & & & & & 3 \\
\hline 27 & $\begin{array}{l}\text { Chances to accomplish } \\
\text { something worth }\end{array}$ & $\mathrm{x}$ & & & $\mathrm{x}$ & & & & & $\mathrm{x}$ & & & & & & & & & & & & & & & & & & & 3 \\
\hline 28 & Safety procedures in site & $\mathrm{x}$ & & & $\mathrm{x}$ & $\mathrm{x}$ & & & & & & & & & & & & & & & & & & & & & & & 3 \\
\hline 29 & Inclement weather & & & & & & $\mathrm{x}$ & & & & & $\mathrm{x}$ & & & & & & & & $\mathrm{x}$ & & & & & & & & & 3 \\
\hline 30 & Site location & & & & & & & & & & $\mathrm{x}$ & $\mathrm{x}$ & & & & & & & & & & & & & & & & $\mathrm{x}$ & 3 \\
\hline 31 & Chances to learn new things & $\mathrm{x}$ & & & $\mathrm{x}$ & & & & & & & & & & & & & & & & & & & & & & & & 2 \\
\hline 32 & $\begin{array}{l}\text { Supervisor's direction and } \\
\text { support }\end{array}$ & $\mathrm{x}$ & & & $\mathrm{x}$ & & & & & & & & & & & & & & & & & & & & & & & & 2 \\
\hline 33 & $\begin{array}{l}\text { Seeing the ultimate results of } \\
\text { work }\end{array}$ & $\mathrm{x}$ & & & $\mathrm{x}$ & & & & & & & & & & & & & & & & & & & & & & & & 2 \\
\hline 34 & Financial security & & $\mathrm{x}$ & & & & & & & & & & & & & & & $\mathrm{x}$ & & & & & & & & & & & 2 \\
\hline 35 & Rework & & & & & & $\mathrm{x}$ & & & & & & & & & & & & & & & & & & $\mathrm{x}$ & & & & 2 \\
\hline
\end{tabular}

1=(Hewage, 2007); 2=(Doloi, 2007); 3=(Dwivedula \& Bredillet, 2010); 4=(Hewage \& Ruwanpura, 2006); 5=(Funso et al., 2016b); 6=(Jarkas et al., 2014); $7=($ Al-Abbadi \& AgyekumMensah, 2019); $8=($ Olomolaiye, 1990); 9=(Shin et al., 2013); 10=(Khan et al., 2011); 11=(Kazaz et al., 2008); 12=(Parkin et al., 2009); 13=(Zakeri et al., 1997); 14=(Ghoddousi et al., 2015); 15=(Nasirzadeh \& Nojedehi, 2013); 16=(Momade \& Hainin, 2019); $17=($ Gunduz \& Abdi, 2020); $18=($ Ohueri et al., 2018$) ; 19=(J a r k a s$ and Radosavljevic, 2013); 20=(Shroff \& Sridhar, 2011); $21=($ Ugulu et al., 2016); 22=(Van Tam et al., 2018); 23=(Enshassi et al., 2007); 24=(Rivas et al., 2011); 25=(McFillen \& Maloney 1988); 26=(Ruthankoon \& Ogunlana, 2003); 27=(Aghayeva \& Ślusarczyk, 2019) 
Engineering managers' recognition and the prospect of promotion are associated with professional development based on employee competency, and predominately show their determination for higher performance (Doloi, 2007). Also, Craftsmen on construction sites will work more productively when they believe there are opportunities for promotion (Ghoddousi et al., 2015).

4.3.4 Job security. Job security has been proposed as a hygiene factor in the theory of two factors by (Herzberg et al., 1959) and as an 'existence need' in the theory of ERG (Existence, Relatedness, and Growth) (Alderfer, 1972). The job security factor is ranked 4th among the top important motivational factors identified in the literature and was identified in 17 different articles. It is obvious that job security is the main influential tool of motivation and puts the individuals very far off from mental tension and they give their best to the companies, ultimately it leads to performance maximization (Sekhar et al., 2013). Zhang (2004) demonstrated that working on an organization with job security, employees get confident with their future career and they put most efforts to gain the goals of their companies (Zhang \& Wu, 2004). Besides, Yamamoto (2013) stated that laborers perceive they will be getting bonuses or rewards for a good job and their work is a secured one, their productivity will automatically be better. In the context of the construction industry, the finding was further support by different studies (Aghayeva \& Ślusarczyk, 2019; Doloi, 2007; Dwivedula \& Bredillet, 2010; Funso et al., 2016b; Ghoddousi et al., 2014; Nasirzadeh \& Nojedehi, 2013), which revealed that job security is a major motivational factor impacting CLP. The study of (Ali et al., 2012) proved that the primacy of job satisfaction for the construction workforce, and this factor is a determinant for the laborers in Iran construction industry.

4.3.5 Good supervision. In this regard, it is controlled based on the inspection of the tasks completed by the workforce. This factor was identified by 16 different publications on motivational factors influencing CLP. The study of (Maloney, 1983) demonstrated the important role of management factor, and to enhance performance, supervisors should positively control and guider workforce. Therefore, occurring an issue about lump laborers cannot be controlled, while companies possessing employed laborers have their effect on employee relations, and subcontractors have no manage or supervise over other subcontractors' workforce (Kazaz et al., 2008). In construction site, supervisors or site engineers, whose major function is to control, supervise, and its numbers are changed depending on the percentage to site area or project characteristics. Hence, the number of construction workers supervised and the responsibility area of each supervisor should be at the optimum level towards performance maximum. The incompetence of supervisors is an issue, workers are highly concerned with the supervision personnel and questions of their competency. Laborers' requirements on their works should be accurately replied by supervisors or inspectors as quickly as possible, in contrast, it is not good for waiting for the answer because it may reduce work productivity and quality (Kazaz et al., 2008; Ng et al., 2004).

4.3.6 Amount of salary. As demonstrated in the previous studies, remuneration was not the only motivational factor, but money was an essential basic need for any individual in order to ensure their lives and prosper (Herzberg et al., 1959; McLeod, 2007). The amount of salary factor was identified by 15 publications on motivational factors affecting labor productivity in the construction sector. Numerous researchers stated that the amount of remuneration is seen as the critical factor to motive construction workforce performance (Aghayeva \& Ślusarczyk, 2019; Enshassi et al., 2007; Funso et al., 2016a; Ghoddousi et al., 2014; Hewage, 2007; Khan et al., 2011; Nasirzadeh \& Nojedehi, 2013; Ohueri et al., 2018; Olomolaiye, 1990; Shroff \& Sridhar, 2011). In many developing countries, construction laborers are facing low-income problems (Ghoddousi et al., 2014; Tabassi \& Bakar, 2009), so the appropriate salary level is the vital role motivator encouraging them to higher performance (Kazaz \& Ulubeyli, 2007; Zakeri et al., 1997). Remuneration is a powerful motivation, the low salary was a primary demotivating to the construction workforce, so without sufficient incomes, it is unlikely that they will conduct their work well. In addition, paying wages on time is also an important factor of any job contract, 
whereas sufficient facilities and a better work climate many leads to reducing the demotivation caused by low income, delaying payment basically do not (Kazaz et al., 2008).

4.3.7 Good work environment. A good work climate with sufficient work conditions may lead to enhance individual job satisfaction and commitment of laborers with their organization, it can make individuals effort their best which may improve labor productivity (Jung \& Kim, 2012). The factor of the good work environment was identified by 14 studies on motivational factors affecting CLP such as (Al-Abbadi \& Agyekum-Mensah, 2019; Doloi, 2007; Funso et al., 2016a; Ghoddousi et al., 2014; Kazaz et al., 2008; Khan et al., 2011; Momade \& Hainin, 2019; Ohueri et al., 2018; Olomolaiye, 1990; Shin et al., 2013). In this regard, the construction workers' environment is approached from the perspective of work content and context. In particular, job content includes a variety of activities related, the experience or practical skills needed, and the challenge tasks provided, whereas, contextual aspects contain work climate, material resources, supervision or inspection, and compensation practices (Maloney, 1986). Employers should perceive the workforce that is concerned with contextual aspects and hence, would be motivated by elements that enhances the working environment in their companies. Besides, working in a bad condition will only sequence negative results due to construction works are physically and mentally demanding, so construction workforce should be worked in a good work environment in order to increase their performance (Dwivedula \& Bredillet, 2010; Sekhar et al., 2013).

\section{Future research areas}

The current study has reviewed the implications of numerous studies on motivational factors affecting labor productivity in the construction industry. As a result, the author has highlighted some knowledge gaps relating to motivational factors toward improving construction workforce productivity which provides a strong platform for further studies as follows:

Depending on the circumstances, the frequency and importance of motivational factors vary from project to project, country to country, and even within the same project (Olomolaiye, Jayawardane, \& Harris, 1998). A large number of motivating factors influencing CLP were identified and evaluated in previous studies so far which draw a comprehensive picture in construction work motivation. Therefore, key motivational factors (i.e., rewards; good relationship; promotion opportunities; job security; good supervision; the amount of salary; good work environment; recognition programs; participation in decision making; and on-time payments) should be examined in more depth in future empirical researches.

The findings also reveal that the previous studies have largely ignored the impact of autonomous work motivation of the construction workforce (i.e., identified regulation; integrated regulation; intrinsic regulation). In the context of the construction industry, almost previous studies on motivational factors which focus controlled motivation such as external regulation and introjected regulation (i.e., external regulation is the prototypical form and reflects behavioral engagement reinforced by rewards of punishment, and introjected regulation reflects participating in behaviors out of a sense of externally referenced obligation like the avoidance of guilt or the promotion of contingent self-worth (Gagné \& Deci, 2005; Ryan \& Deci, 2000)). However, in recently, starting a study focuses on autonomous motivation like study was conducted by (Johari \& Jha, 2020) which indicated that various variables impacting work motivation on construction workers to build multistory residential buildings in India such as amotivation; extrinsic regulation (social); extrinsic regulation (material); introjected regulation; identified regulation; intrinsic motivation. A clear gap exists in the literature concerning the identification of variables influencing CLP from the perspective of autonomous work motivation, hence, it is further recommended that future studies should focus to solve this knowledge gap.

\section{Conclusions and limitations}

Work motivation as a catalyzer for the construction workforce to complete the task in a much better way than they usually do which may lead to improve working performance in construction 
projects (Sekhar et al., 2013). In this study, the authors analyzed the findings of previous studies on motivational factors affecting labor productivity in the construction industry on the basis of examining a comprehensive literature review. the analysis results indicated that the majority of studies were conducted in Asian counties, followed by Europe, Africa, America, and Australia Pacific; Qatar, Iran, Turkey, and Nigeria have a higher number of publications to contribute to studying motivational factors affecting CLP. However, having a big knowledge gap as no research to the date has been carried out in nations of the South American continent, and several studies were conducted in Australia Pacific, Africa, and Europe. This study indicated that almost previous studies adopted the methods of empirical research for identifying and evaluating of motivational factors with a prevalent procedure includes 5 -step is that identifying motivational factors on the basis of a review of existing literature; pilot study; data collection; data analysis; and concluding critical motivational factors.

Utilizing analysis of the 27 publications related to motivational factors impacting CLP. It was found that numerous critical factors impacting labor productivity in the construction sector, but the top comment motivational factors that have the most impact on labor productivity in the construction industry are rewards; good relationship; promotion opportunities; job security; good supervision; the amount of salary; and good work environment. Therefore, it is encouraged that engineering managers, project managers, employers should focus on top influential factors to ensure effective management and improve the productivity of the construction workforce. This study has provided a general overview of the development of motivational factors affecting CLP, hence formed a solid platform for scientists for further studies. Besides, from knowledge gaps were explained, it is recommended that the checklist of motivational factors impacting labor productivity in the construction industry developed in this study would be used for further analysis to allow for comparison to the results identified in this study.

The study's principal weakness is that the use of specific keywords to find papers on this area does not cover all possible possibilities. As a result, the research findings may not fully reflect the total literature on this topic. This study used a Scopus dataset, therefore any limitations in Scopus coverage in publications could have an impact on the quality of the data used. Future studies should be conducted on a regular basis to address the limits of using data from various sources, search algorithms, and strategies.

\section{References}

Aghayeva, K., \& Ślusarczyk, B. (2019). Analytic hierarchy of motivating and demotivating factors affecting labor productivity in the construction industry: the case of Azerbaijan. Sustainability, 11(21), 5975. https://doi.org/10.3390/su11215975

Ailabouni, N., Gidado, K., \& Painting, N. (2009). Factors affecting employee productivity in the UAE construction industry. Paper presented at the 25th Annual ARCOM Conference, Nottingham, UK.

Al-Abbadi, G. M. d., \& Agyekum-Mensah, G. (2019). The effects of motivational factors on construction professionals productivity in Jordan. International Journal of Construction Management, 1-12. https://doi.org/10.1080/15623599.2019.1652951

Alderfer, C. P. (1972). Existence, relatedness, and growth: Human needs in organizational settings. Free Press.

Ali, H. N., Monika, M., Kiamars, F. H., \& Kalajahi, S. R. T. (2012). Identifying and prioritizing the motivational factors of employees through MCDM approach. Journal of Basic and Applied Scientific Research, 2(10), 9814-9821.

Alinaitwe, H. M., Mwakali, J. A., \& Hansson, B. (2007). Factors affecting the productivity of building craftsmen-studies of Uganda. Journal of Civil Engineering and Management, 13(3), 169-176. https://doi.org/10.1080/13923730.2007.9636434

Arditi, D., \& Mochtar, K. (2000). Trends in productivity improvement in the US construction industry. Construction Management \& Economics, 18(1), 15-27. https://doi.org/10.1080/014461900370915

Ayele, S., \& Fayek, A. R. (2019). A framework for total productivity measurement of industrial construction projects. Canadian Journal of Civil Engineering, 46(3), 195-206. https://doi.org/10.1139/cjce-2018-0020

Barg, J. E., Ruparathna, R., Mendis, D., \& Hewage, K. N. (2014). Motivating workers in construction. Journal of Construction Engineering, 3(2), 21-35. http://dx.doi.org/10.1155/2014/703084

Borcherding, J. D. (1976). Improving productivity in industrial construction. Journal of the Construction Division, 102(4), 599-614. https://doi.org/10.1061/JCCEAZ.0000641 
Chitkara, K. (1998). Construction project management: Tata McGraw-Hill Education.

Corporation, I. F. (2018). Construction Industry Value Chain: How Companies are Using Carbon Pricing to Address Climate Risk and Find New Opportunities. Retrieved from http://hdl.handle.net/10986/31055

Cox, R. F., Issa, R. R., \& Koblegard, K. (2005). Management's perception of key behavioral indicators for construction. Journal of Construction Engineering and Management, 131(3), 368-376. https://doi.org/10.1061/(ASCE)0733-9364(2005)131:3(368)

Dixit, S., Pandey, A. K., Mandal, S. N., \& Bansal, S. (2017). A study of enabling factors affecting construction productivity: Indian scnerio. International Journal of Civil Engineering \& Technology, 8(6), 741-758.

Doloi, H. (2007). Twinning motivation, productivity and management strategy in construction projects. Engineering Management Journal, 19(3), 30-40. https://doi.org/10.1080/10429247.2007.11431738

Doloi, H. (2008). Application of AHP in improving construction productivity from a management perspective. Construction Management and Economics, 26(8), 841-854. https://doi.org/10.1080/01446190802244789

Drucker, P. F. (1993). Managing in turbulent times. Routledge.

Dwivedula, R., \& Bredillet, C. N. (2010). Profiling work motivation of project workers. International Journal of Project Management, 28(2), 158-165. https:/ / doi.org/10.1016/j.ijproman.2009.09.001

Egan, J. (1998). Retbinking construction. The report of the construction task force. Department of Environment, Transport and the Region, UK.

Enshassi, A., Mohamed, S., Mustafa, Z. A., \& Mayer, P. E. (2007). Factors affecting labour productivity in building projects in the Gaza Strip. Journal of Civil Engineering and Management, 13(4), 245-254. https://doi.org/10.1080/13923730.2007.9636444

Falagas, M. E., Pitsouni, E. I., Malietzis, G. A., \& Pappas, G. (2008). Comparison of PubMed, Scopus, web of science, and Google scholar: strengths and weaknesses. The FASEB journal, 22(2), 338-342. https://doi.org/10.1096/fj.07-9492LSF

Fellows, R. F., \& Liu, A. M. (2015). Research methods for construction: John Wiley \& Sons.

Funso, A. (2016). Motivation and its impact on workers' productivity in construction firms in Lagos, Nigeria. PhD. Thesis, Kenyatta University.

Funso, A., Sammy, L., \& Gerryshom, M. (2016a). Application of motivation in Nigeria construction industry: Factor analysis approach. International Journal of Economics and Finance, 8(5), 271-276. http://dx.doi.org/10.5539/ijef.v8n4p271

Funso, A., Sammy, L., \& Gerryshom, M. (2016b). Impact of motivation on productivity of craftsmen in construction firms in Lagos, Nigeria. International Journal of Economics and Finance, 8(4), 271-276. http://dx.doi.org/10.5539/ijef.v8n4p271

Gagné, M., \& Deci, E. L. (2005). Self-determination theory and work motivation. Journal of Organizational Behavior, 26(4), 331-362. https://doi.org/10.1002/job.322

García-Izquierdo, A. L., Moscoso, S., \& Ramos-Villagrasa, P. J. (2012). Reactions to the Fairness of Promotion Methods: Procedural justice and job satisfaction. International Journal of Selection and Assessment, 20(4), 394-403. https://doi.org/10.1111/ijsa.12002

Ghoddousi, P., Bahrami, N., Chileshe, N., \& Hosseini, M. R. (2014). Mapping site-based construction workers' motivation: Expectancy theory approach. Australasian Journal of Construction Economics and Building, 14(1), 60-77. https://doi.org/10.5130/ajceb.v14i1.3712

Ghoddousi, P., \& Hosseini, M. R. (2012). A survey of the factors affecting the productivity of construction projects in Iran. Technological and Economic Development of Economy, 18(1), 99-116. https://doi.org/10.3846/20294913.2012.661203

Ghoddousi, P., Poorafshar, O., Chileshe, N., \& Hosseini, M. R. (2015). Labour productivity in Iranian construction projects. International Journal of Productivity and Performance Management.

Gunduz, M., \& Abdi, E. A. (2020). Motivational Factors and Challenges of Cooperative Partnerships between Contractors in the Construction Industry. Journal of Management in Engineering, 36(4), 04020018. https://doi.org/10.1061/(ASCE)ME.1943-5479.0000773

Haas, C., Goodrum, P., \& Caldas, C. (2008). Leveraging technology to improve construction productivity. RS240-1, Construction Industry Institute, Univ. of Texas at Austin, Austin, TX.

Hai, D. T., \& Van Tam, N. (2019). Application of the Regression Model for Evaluating Factors Affecting Construction Workers' Labor Productivity in Vietnam. The Open Construction \& Building Technology Journal, 13(1), 353-362. https://doi.org/10.2174/1874836801913010353

Hamza, M., Shahid, S., Bin Hainin, M. R., \& Nashwan, M. S. (2019). Construction labour productivity: review of factors identified. International Journal of Construction Management, 1-13. https://doi.org/10.1080/15623599.2019.1627503

Hasan, A., Baroudi, B., Elmualim, A., \& Rameezdeen, R. (2018). Factors affecting construction productivity: a 30 year systematic review. Engineering, Construction and Architectural Management. https://doi.org/10.1108/ECAM-02-2017-0035

Hazeltine, C. S. (1976). Motivation of construction workers. Journal of the Construction Division, 102(CO3). https://doi.org/10.1061/JCCEAZ.0000626 
Herzberg, F., Mausner, B., \& Snyderman, B. B. (1959). The Motivation to Work. New York: John Wiley \& Sons. Inc.

Hewage, K. N. (2007). Construction productivity improvement by worker motivation and IT based communication. (Ph.D. Dissertation), The University of Calgary, Calgary, Canada.

Hewage, K. N., \& Ruwanpura, J. Y. (2006). Carpentry workers issues and efficiencies related to construction productivity in commercial construction projects in Alberta. Canadian Journal of Civil Engineering, 33(8), 1075-1089. https://doi.org/10.1139/106-050

Hong, Y., \& Chan, D. W. (2014). Research trend of joint ventures in construction: a two-decade taxonomic review. Journal of Facilities Management. https://doi.org/10.1108/JFM-04-2013-0022

Jarkas, A. M. (2010). Buildability factors influencing micro-level formwork labour productivity of slab panels in building floors. Architectural Engineering And Design Management, 6(3), 161-174. https://doi.org/10.3763/aedm.2009.0107

Jarkas, A. M., \& Bitar, C. G. (2012). Factors affecting construction labor productivity in Kuwait. Journal of Construction Engineering and Management, 138(7), 811-820. https://doi.org/10.1061/(ASCE)CO.19437862.0000501

Jarkas, A. M., \& Radosavljevic, M. (2013). Motivational factors impacting the productivity of construction master craftsmen in Kuwait. Journal of Management in Engineering, 29(4), 446-454. https://doi.org/10.1061/(ASCE)ME.1943-5479.0000160

Jarkas, A. M., Radosavljevic, M., \& Wuyi, L. (2014). Prominent demotivational factors influencing the productivity of construction project managers in Qatar. International Journal of Productivity and Performance Management, 63(8), 1070-1090. https://doi.org/10.1108/IJPPM-11-2013-0187

Jenkins, J., Douglas, G., \& Laufer, A. (1982). Improving construction productivity: the case for motivation. AACE Transactions.

Johari, S., \& Jha, K. N. (2020). Impact of Work Motivation on Construction Labor Productivity. Journal of management in engineering, 36(5), 04020052. https://doi.org/10.1061/(ASCE)ME.1943-5479.0000824

Jung, J., \& Kim, Y. (2012). Causes of newspaper firm employee burnout in Korea and its impact on organizational commitment and turnover intention. The International Journal of Human Resource Management, 23(17), 3636-3651. https://doi.org/10.1080/09585192.2012.654806

Kazaz, A., \& Ac1kara, T. (2015). Comparison of labor productivity perspectives of project managers and craft workers in Turkish construction industry. Procedia Computer Science, 64, 491-496. https://doi.org/10.1016/j.procs.2015.08.548

Kazaz, A., Manisali, E., \& Ulubeyli, S. (2008). Effect of basic motivational factors on construction workforce productivity in Turkey. Journal of Civil Engineering and Management, 14(2), 95-106. https://doi.org/10.3846/1392-3730.2008.14.4

Kazaz, A., \& Ulubeyli, S. (2007). Drivers of productivity among construction workers: A study in a developing country. Building and Environment, 42(5), 2132-2140. https://doi.org/10.1016/j.buildenv.2006.04.020

Ke, Y., Wang, S., Chan, A. P., \& Cheung, E. (2009). Research trend of public-private partnership in construction journals. Journal of construction engineering and management, 135(10), 1076-1086. https://doi.org/10.1061/(ASCE)0733-9364(2009)135:10(1076)

Khan, A., Umer, M., \& Khan, S. M. (2011). Effect of basic motivational factors on construction workforce productivity in Pakistan. Sri Lanka: Library, University of Moratuwah. ttp://dl.lib.mrt.ac.lk/bitstream/handle/123/9453/SEC-11-85.pdf

Koch, A. K., \& Nafziger, J. (2012). Job assignments under moral hazard: The Peter principle revisited. Journal of Economics \& Management Strategy, 21(4), 1029-1059. https://doi.org/10.1111/j.15309134.2012.00347.x

Laufer, A., \& Borcherding, J. D. (1981). Financial incentives to raise productivity. Journal of the Construction Division, 107(4), 745-756. https://doi.org/10.1061/JCCEAZ.0001002

Lim, E. C., \& Alum, J. (1995). Construction productivity: issues encountered by contractors in Singapore. International Journal of Project Management, 13(1), 51-58. https://doi.org/10.1016/0263-7863(95)95704$\mathrm{H}$

Lingard, H., \& Francis, V. (2006). Does a supportive work environment moderate the relationship between work-family conflict and burnout among construction professionals? Construction Management and Economics, 24(2), 185-196. https://doi.org/10.1080/14697010500226913

Maloney, W. F. (1983). Productivity improvement: The influence of labor. Journal of construction engineering and management, 109(3), 321-334. https://doi.org/10.1061/(ASCE)0733-9364(1983)109:3(321)

Maloney, W. F. (1986). Understanding motivation. Journal of Management in Engineering, 2(4), 231-245.

Maloney, W. F., \& McFillen, J. M. (1987). Motivational impact of work crews. Journal of construction engineering and management, 113(2), 208-221. https://doi.org/10.1061/(ASCE)0733-9364(1987)113:2(208)

McFillen, J., \& Maloney, W. F. (1988). New answers and new questions in construction worker motivation. Construction management and economics, 6(1), 35-48.

McLeod, S. (2007). Maslow's hierarchy of needs. Simply Psychology, 1, 1-8. 
Momade, M. H., \& Hainin, M. R. (2019). Identifying motivational and demotivational productivity factors in Qatar construction projects. Engineering, Technology and Applied Science Research, 9(2), 3945-3948. https://doi.org/10.48084/etasr.2577

Nasirzadeh, F., \& Nojedehi, P. (2013). Dynamic modeling of labor productivity in construction projects. International Journal of Project Management, 31(6), 903-911. https://doi.org/10.1016/j.ijproman.2012.11.003

Ng, S. T., Skitmore, R. M., Lam, K. C., \& Poon, A. W. (2004). Demotivating factors influencing the productivity of civil engineering projects. International Journal of Project Management, 22(2), 139-146. https://doi.org/10.1016/S0263-7863(03)00061-9

Ohueri, C. C., Enegbuma, W. I., Wong, N. H., Kuok, K. K., \& Kenley, R. (2018). Labour productivity motivation framework for Iskandar Malaysia. Built Environment Project and Asset Management, 8(3). 293304. https://doi.org/10.1108/BEPAM-09-2017-0070

Olomolaiye, P. O., Jayawardane, A., \& Harris, F. (1998). Construction Productivity Management. Longman Pub Group

Olomolaiye, P. O. (1990). An evaluation of the relationships between bricklayers' motivation and productivity. Construction Management and Economics, 8(3), 301-313. https://doi.org/10.1080/01446199000000025

Osei-Kyei, R., \& Chan, A. P. (2015). Review of studies on the Critical Success Factors for Public-Private Partnership (PPP) projects from 1990 to 2013. International Journal of Project Management, 33(6), 1335 1346. https://doi.org/10.1016/j.ijproman.2015.02.008

Parkin, A. B., Tutesigensi, A., \& Büyükalp, A. I. (2009). Motivation among construction workers in Turkey. In: Dainty, A.R.J., (ed.) Proceedings 25th Annual Conference. 25th Annual ARCOM Conference, 7-9 September, Nottingham, UK. ISBN 978-0-9552390-2-1. https://eprints.whiterose.ac.uk/9870/

Rivas, R. A., Borcherding, J. D., González, V., \& Alarcón, L. F. (2011). Analysis of factors influencing productivity using craftsmen questionnaires: case study in a Chilean construction company. Journal of construction engineering and management, 137(4), 312-320. https://doi.org/10.1061/(ASCE)CO.19437862.0000274

Robles, G., Stifi, A., Ponz-Tienda, J. L., \& Gentes, S. (2014). Labor productivity in the construction industryfactors influencing the Spanish construction labor productivity. International Journal of Civil, Environmental, Structural, Construction and Architectural Engineering, 8(10), 1021-1030. https://doi.org/10.5281/zenodo.1096495

Ruthankoon, R., \& Ogunlana, S. O. (2003). Testing Herzberg's two-factor theory in the Thai construction industry. Engineering, Construction and Architectural Management, 10(5), 333-341. https://doi.org/10.1108/09699980310502946

Ryan, R. M., \& Deci, E. L. (2000). Intrinsic and extrinsic motivations: Classic definitions and new directions. Contemporary Educational Psychology, 25(1), 54-67. https://doi.org/10.1006/ceps.1999.1020

Schmid, B., \& Adams, J. (2008). Motivation in project management: The project manager's perspective. Project Management Journal, 39(2), 60-71. https://doi.org/10.1002/pmj.20042

Schrader, C. R. (1972). Motivation of construction craftsmen. Journal of the Construction Division, $98(2), 257-$ 273. https://doi.org/10.1061/JCCEAZ.0000348

Segerstedt, A., Olofsson, T., Bankvall, L., Bygballe, L. E., Dubois, A., \& Jahre, M. (2010). Interdependence in supply chains and projects in construction. Supply Chain Management, 15(5). 385-393. https:/ / doi.org/10.1108/13598541011068314.

Sekhar, C., Patwardhan, M., \& Singh, R. K. (2013). A literature review on motivation. Global business perspectives, 1(4), 471-487. https://doi.org/10.1007/s40196-013-0028-1

Shin, Y. S., Kim, J. D., Kim, T. Y., \& Kim, G. H. (2013). Construction productivity factors affected by the motivation of foreign laborers in construction fields. Applied Mechanics and Materials (vol. 357-360). https://doi.org/10.4028/www.scientific.net/AMM.357-360.2599

Shoar, S., \& Banaitis, A. (2019). Application of fuzzy fault tree analysis to identify factors influencing construction labor productivity: a high-rise building case study. Journal of Civil Engineering and Management, 25(1), 41-52. https://doi.org/10.3846/jcem.2019.7785

Shroff, R. P., \& Sridhar, S. (2011). Study of motivators and demotivators affecting the performance of employees in the construction industry-an exploratory study. International Journal of Construction Management, 11(3), 49-66. https://doi.org/10.1080/15623599.2011.10773172

Soekiman, A., Pribadi, K., Soemardi, B., \& Wirahadikusumah, R. (2011). Factors relating to labor productivity affecting the project schedule performance in Indonesia. Procedia Engineering, 14, 865-873. https://doi.org/10.1016/j.proeng.2011.07.110

Tabassi, A. A., \& Bakar, A. A. (2009). Training, motivation, and performance: The case of human resource management in construction projects in Mashhad, Iran. International journal of project management, 27(5), 471-480. https://doi.org/10.1016/j.ijproman.2008.08.002

Timmer, M. P., Inklaar, R., O'Mahony, M., \& Van Ark, B. (2010). Economic growth in Europe: A comparative industry perspective: Cambridge University Press. 
Tookey, J. E. (2011). Labour productivity in the New Zealand construction industry: A thorough investigation. Australasian Journal of Construction Economics and Building, 11(1), 41-60.

Tsai, C. C., \& Lydia Wen, M. (2005). Research and trends in science education from 1998 to 2002: A content analysis of publication in selected journals. International Journal of Science Education, 27(1), 3-14. https://doi.org/10.1080/0950069042000243727

Ugulu, R., Makhotso, M., Mahlatse, R., Morongoa, S., \& Allen, S. (2016). The influence of motivation on labour productivity on building construction projects in South Africa. International Journal of Scientific \& Engineering Research, 7(4), 1066-1073.

Van Tam, N. (2021). Scientometric Review of Research Trends on Public Private Partnership (PPP) for Infrastructure Projects From 2000 to 2020. CSID Journal of Infrastructure Development, 4(1), 32. https://doi.org/10.32783/csid-jid.v4i1.215

Van Tam, N., Diep, T. N., Quoc Toan, N., \& Le Dinh Quy, N. (2021). Factors affecting adoption of building information modeling in construction projects: A case of Vietnam. Cogent Business \& Management, 8(1), 1918848. https://doi.org/10.1080/23311975.2021.1918848

Van Tam, N., Huong, N. L., \& Ngoc, N. B. (2018). Factors affecting labour productivity of construction worker on construction site: A case of Hanoi. Journal of Science and Technology in Civil Engineering (STCE)NUCE, 12(5), 127-138. https://doi.org/10.31814/stce.nuce2018-12(5)-13

Van Tam, N., Toan, N. Q., Van Phong, V., \& Durdyev, S. (2021). Impact of BIM-related factors affecting construction project performance. International Journal of Building Pathology and Adaptation. https://doi.org/10.1108/IJBPA-05-2021-0068

Van, T. N., \& Quoc, T. N. (2021). Research Trends on Machine Learning in Construction Management: A Scientometric Analysis. Journal of Applied Science and Technology Trends, 2(03), 96-104. https://doi.org/10.38094/jastt203105

Yamamoto, H. (2013). The relationship between employees' perceptions of human resource management and their retention: From the viewpoint of attitudes toward job-specialties. The International Journal of Human Resource Management, 24(4), 747-767. https://doi.org/10.1080/09585192.2012.697478

Yuan, H., \& Shen, L. (2011). Trend of the research on construction and demolition waste management. Waste management, 31(4), 670-679. https://doi.org/10.1016/j.wasman.2010.10.030

Zakeri, M., Olomolaiye, P., Holt, G., \& Harris, F. (1997). Factors affecting the motivation of Iranian construction operatives. Building and Environment, 32(2), 161-166. https://doi.org/10.1016/S03601323(96)00044-3

Zakeri, M., Olomolaiye, P. O., Holt, G. D., \& Harris, F. C. (1996). A survey of constraints on Iranian construction operatives' productivity. Construction Management \& Economics, 14(5), 417-426. https://doi.org/10.1080/014461996373287 